\title{
Mechanical properties and fracture behaviour of ODS Steel Friction Stir Welds at variable temperatures
}

DOI:

10.1016/j.msea.2017.03.090

\section{Document Version}

Accepted author manuscript

Link to publication record in Manchester Research Explorer

\section{Citation for published version (APA):}

Dawson, H., Serrano, M., Hernandez, R., Cater, S., \& Jimenez-Melero, E. (2017). Mechanical properties and fracture behaviour of ODS Steel Friction Stir Welds at variable temperatures. Materials Science and Engineering A, 693, 84-92. https://doi.org/10.1016/j.msea.2017.03.090

\section{Published in:}

Materials Science and Engineering A

\section{Citing this paper}

Please note that where the full-text provided on Manchester Research Explorer is the Author Accepted Manuscript or Proof version this may differ from the final Published version. If citing, it is advised that you check and use the publisher's definitive version.

\section{General rights}

Copyright and moral rights for the publications made accessible in the Research Explorer are retained by the authors and/or other copyright owners and it is a condition of accessing publications that users recognise and abide by the legal requirements associated with these rights.

\section{Takedown policy}

If you believe that this document breaches copyright please refer to the University of Manchester's Takedown Procedures [http://man.ac.uk/04Y6Bo] or contact uml.scholarlycommunications@manchester.ac.uk providing relevant details, so we can investigate your claim.

\section{OPEN ACCESS}




\section{Author's Accepted Manuscript}

Mechanical properties and fracture behaviour of ODS Steel Friction Stir Welds at variable temperatures

H. Dawson, M. Serrano, R. Hernandez, S. Cater, E. Jimenez-Melero

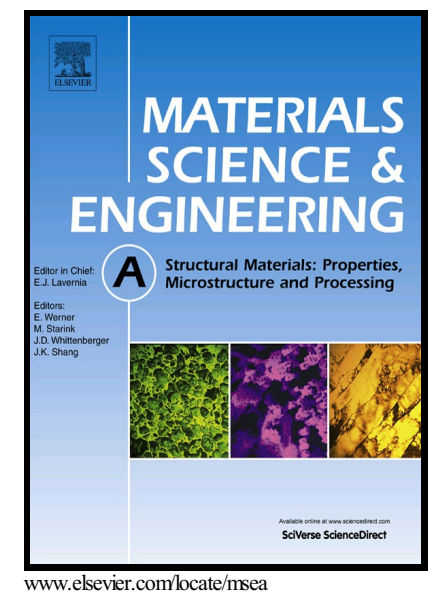

PII: $\quad$ S0921-5093(17)30406-9

DOI: $\quad$ http://dx.doi.org/10.1016/j.msea.2017.03.090

Reference: MSA34873

To appear in: $\quad$ Materials Science \& Engineering $A$

Received date: 5 February 2017

Revised date: 22 March 2017

Accepted date: 23 March 2017

Cite this article as: H. Dawson, M. Serrano, R. Hernandez, S. Cater and E Jimenez-Melero, Mechanical properties and fracture behaviour of ODS Steє Friction Stir Welds at variable temperatures, Materials Science \& Engineering $A$ http://dx.doi.org/10.1016/j.msea.2017.03.090

This is a PDF file of an unedited manuscript that has been accepted fo publication. As a service to our customers we are providing this early version o the manuscript. The manuscript will undergo copyediting, typesetting, an review of the resulting galley proof before it is published in its final citable form Please note that during the production process errors may be discovered whic could affect the content, and all legal disclaimers that apply to the journal pertain 


\title{
ACCEPTED MANUSCRIPT
}

\section{Mechanical properties and fracture behaviour of ODS Steel Friction Stir Welds at variable temperatures}

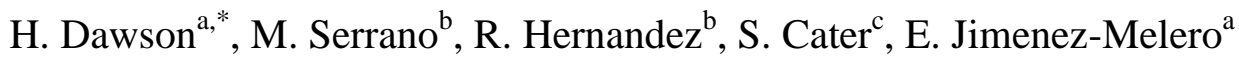 \\ ${ }^{a}$ School of Materials, University of Manchester, Manchester M13 9PL, \\ United Kingdom \\ ${ }^{b}$ Structural Materials Division, Technology Department, CIEMAT, \\ Avda de la Complutense 40, 28040 Madrid, Spain \\ ${ }^{c}$ Friction and Forge Processes Department, Joining Technologies Group, TWI \\ Technology Centre (Yorkshire), Advanced Manufacturing Park, Wallis Way, Catcliffe, \\ Rotherham S60 5TZ, United Kingdom
}

\begin{abstract}
*Corresponding author :H. Dawson, A11, The Mill, School of Materials, University of Manchester, Manchester, M13 9PL, United Kingdom, Tel.: +44 (0)7984657227, Email: huwdawson@gmail.com
\end{abstract}

\begin{abstract}
We have assessed the microstructure and the temperature-dependent mechanical behaviour of five bead-on-plate friction stir welds of Oxide Dispersion Strengthened (ODS) steel, produced using systematic changes to the tool rotation and traverse speed. Friction stir welding can potentially retain the fine dispersion of nanoparticles, and therefore also the high-temperature strength and radiation damage resistance of these materials. Tensile testing was carried out on the MA956 base material at a range of temperatures, from room temperature up to $750^{\circ} \mathrm{C}$. The mechanical properties of the welds were investigated via tensile testing at room temperature and at $500^{\circ} \mathrm{C}$, together with micro-hardness testing. The welds exhibited similar strength and ductility to the base material at both testing temperatures
\end{abstract}




\section{ACCEPTED MANUSCRIPT}

as welding caused a partial loss of particle strengthening, alongside an increase in grain boundary strengthening due to a greatly refined grain size in the stir zones. The microhardness data revealed a trend of increasing hardness with increasing tool traverse speed or decreasing rotation speed. This was attributed to the smaller grain size and lower nanoparticle number density in the welds created with these parameters. At $500^{\circ} \mathrm{C}$, the yield stress and ultimate tensile stress of the base material and the welds decreased, due to a progressive reduction in both the Orowan-type particle strengthening and the grain boundary strengthening.

\section{Keywords:}

ODS steel, friction stir welding, mechanical characterization, fracture, electron microscopy, hardness measurement

\section{Introduction}

Friction Stir Welding (FSW) is currently being investigated as a suitable method of joining the difficult-to-weld Oxide Dispersion Strengthened (ODS) steels, for use as structural materials in future generation nuclear fission and fusion reactors [1-3]. The ODS steel microstructure comprises in general of a fine homogeneous dispersion of $\mathrm{Y}(\mathrm{Al}, \mathrm{Ti})$ oxide nano-particles embedded in an Fe-Cr ferritic matrix [4,5]. The nanoparticles strengthen the material to high temperatures by hindering dislocation and grain boundary motion through the matrix. Moreover, the nano-particle/matrix interfaces act as trapping sites for transmutant helium, and also as recombination sites for radiation-induced vacancies and self-interstitials, and therefore help to improve the damage resistance of these materials to high radiation doses [6,7]. As a solid state technique, FSW can potentially join ODS steels with a minimal level of disruption to the nanoparticle dispersion in the matrix since no melting should occur. During 


\section{ACCEPTED MANUSCRIPT}

FSW, the peak temperatures do not normally exceed $70-90 \%$ of the melting point of the material to be welded [8].

Recently several authors have reported successfully joined ODS steels via FSW [9-12]. However, the particle dispersions in the welded region of the specimen still tend to have deleterious agglomeration, dissolution or coarsening. This is usually accompanied by other significant changes to the microstructure such as grain coarsening, development of bcc torsional texture or changes to the dislocation density, due to the dynamic recrystallization process induced by FSW. These microstructural changes normally soften the welded areas with respect to the base material and, in the harsh nuclear environments to which ODS steels will be subject, even subtle microstructural changes may have critical implications for the weld's structural integrity and therefore for the safe operation of the nuclear power plant.

In order for Friction Stir Welded ODS steel to be approved for use in nuclear reactor environments, it is of paramount importance that the mechanical properties of the welded regions, along with the base material, be comprehensively examined, including the material's behaviour at elevated temperatures. This should be linked to the impact of key welding parameters and the microstructural properties of the welds, so that the grain structure and mechanical performance of the friction stir welds can be as close as possible, if not preferable, to the base material. Although some limited research has in recent years been conducted on the mechanical properties of Friction Stir Welded ODS steels [9-11], including the MA956 steel which is the subject of this study, the data is still highly fragmented. This is partly due to the fact that research into FSW of steels is still in its relative infancy $[13,14]$, and partly to the fact that many ODS steel grades proposed for use in nuclear reactors [15] are currently in limited supply. It is therefore difficult to obtain systematic experimental data on a relatively large range of welding parameters and testing temperatures, so that the process parameter windows can be selected for optimal heat input and flow of the plasticised material 


\section{ACCEPTED MANUSCRIPT}

during welding. This paper analyses the mechanical properties of five welds produced using systematic variations in tool rotation and traverse speeds, combining tensile testing at variable temperatures, micro-hardness mapping and electron microscopy, and aims to link these to the microstructural characteristics of the welds.

\section{Experimental}

\subsection{Friction Stir Welding}

Table 1. Chemical composition of the studied MA956 ODS steel (wt\%).

$\begin{array}{cccccccccccccccc}\mathrm{Cr} & \mathrm{Al} & \mathrm{Y}_{2} \mathrm{O}_{3} & \mathrm{P} & \mathrm{Ti} & \mathrm{O} & \mathrm{C} & \mathrm{Mn} & \mathrm{Si} & \mathrm{Mo} & \mathrm{Ni} & \mathrm{Co} & \mathrm{N} & \mathrm{Cu} & \mathrm{S} & \mathrm{Fe} \\ 19.97 & 4.44 & 0.53 & 0.53 & 0.33 & 0.21 & 0.15 & 0.11 & 0.05 & <0.05 & 0.04 & 0.03 & 0.022 & 0.009 & 0.004 & \text { bal. }\end{array}$

The chemical composition of the fully ferritic MA956 ODS steel used in this study is shown in Table 1. The MA956 plate was manufactured by Special Metals Corporation, UK, via mechanical alloying and subsequent consolidation by extrusion. The material was then hot rolled in both the longitudinal and transverse directions [16-18] at temperatures between 900 and $1100^{\circ} \mathrm{C}$, followed by a one hour annealing treatment at $1320^{\circ} \mathrm{C}$ and a final air cooling step to room temperature. Five bead-on-plate friction stir welds were carried out on two nominally $4 \mathrm{~mm}$-thick plates, which were produced by slicing the original plate in half through its thickness. A polycrystalline cubic boron nitride tool, with a $25 \mathrm{~mm}$ shoulder and $3 \mathrm{~mm}$ pin, and a downforce of $25 \mathrm{kN}$ was used for all of the welds. Systematic variations of the tool rotation and traverse speeds were selected in this study, see Table 2. Micro-hardness maps of the weld cross sections were obtained using a Struers Durascan automatic indenter with a $0.5 \mathrm{kgf}\left(\mathrm{HV}_{0.5}\right)$. The maps were derived from lines of indentations with $0.5 \mathrm{~mm}$ spacings.

Table 2. Welding parameters, i.e. tool traverse and rotation speed, used for the associated weld number.

$\begin{array}{lcc}\text { Weld } & \text { Rotations } & \text { Traverse } \\ \text { No. \# } & \text { per Minute } & \text { Speed } \\ & (\mathbf{r p m}) & (\mathbf{m m} / \mathbf{m i n})\end{array}$




$\begin{array}{ccc}\text { ACCEPTED MANUSCF } & \text { MAN } \\ \mathbf{1} & 200 & 140 \\ \mathbf{2} & 200 & 120 \\ \mathbf{3} & 200 & 160 \\ \mathbf{4} & 220 & 140 \\ \mathbf{5} & 180 & 140\end{array}$

\subsection{Optical and Electron Microscopy}

The macroscopic structure of the weld cross sections was revealed by etching with a solution of 15 vol. $\% \mathrm{HCl}$ and 3 vol. $\% \mathrm{HNO}_{3}$, and afterwards collecting optical micrographs using a Keyence VK-X200K 3D Laser Scanning Confocal Microscope. The microstructure of the welded regions was studied by acquiring backscattered electron (BSE) images on an FEI Magellan High Resolution FEG-SEM using an accelerating voltage of $2 \mathrm{kV}$, and transmission electron micrographs were taken on an FEI Tecnai $20200 \mathrm{kV}$ Analytical Electron Microscope. $3 \mathrm{~mm}$-diameter TEM discs were prepared by electropolishing at a temperature of $-40^{\circ} \mathrm{C}$, using a Tenupol 5 Jet electropolisher and an electrolyte of 90 vol.\% methanol and 10 vol.\% perchloric acid. Scanning electron micrographs of the fracture surfaces after tensile testing were taken on a Carl Zeiss Auriga Compact field effect SEM using an accelerating voltage of $25 \mathrm{kV}$.

\subsection{Tensile Testing}

Dog-bone tensile specimens with a gauge length of $15 \mathrm{~mm}$ and a cross section of $3 \times 2 \mathrm{~mm}^{2}$ were machined by electrical discharge machining from the transverse-longitudinal plane of the welds. The weld tensile specimens were taken from the top $2 \mathrm{~mm}$ of the weld, with the longest axis of the specimens lying perpendicular to the weld line; such specimens after testing can be seen in the inserts of Fig. 8. Specimens of the base material were machined so that they were comprised of only the coarse grained microstructure, as discussed in section 3.1. Tensile tests were performed under stroke control with a displacement rate of $0.1 \mathrm{~mm} / \mathrm{min}$, using a MTS servo-hydraulic testing machine. Tests on the base material were 


\section{ACCEPTED MANUSCRIPT}

carried out at a range of temperatures from room temperature to $750^{\circ} \mathrm{C}$, whereas tests on the weld specimens were conducted at room temperature and $500^{\circ} \mathrm{C}$.

\section{Results}

\subsection{Structural Characterisation}
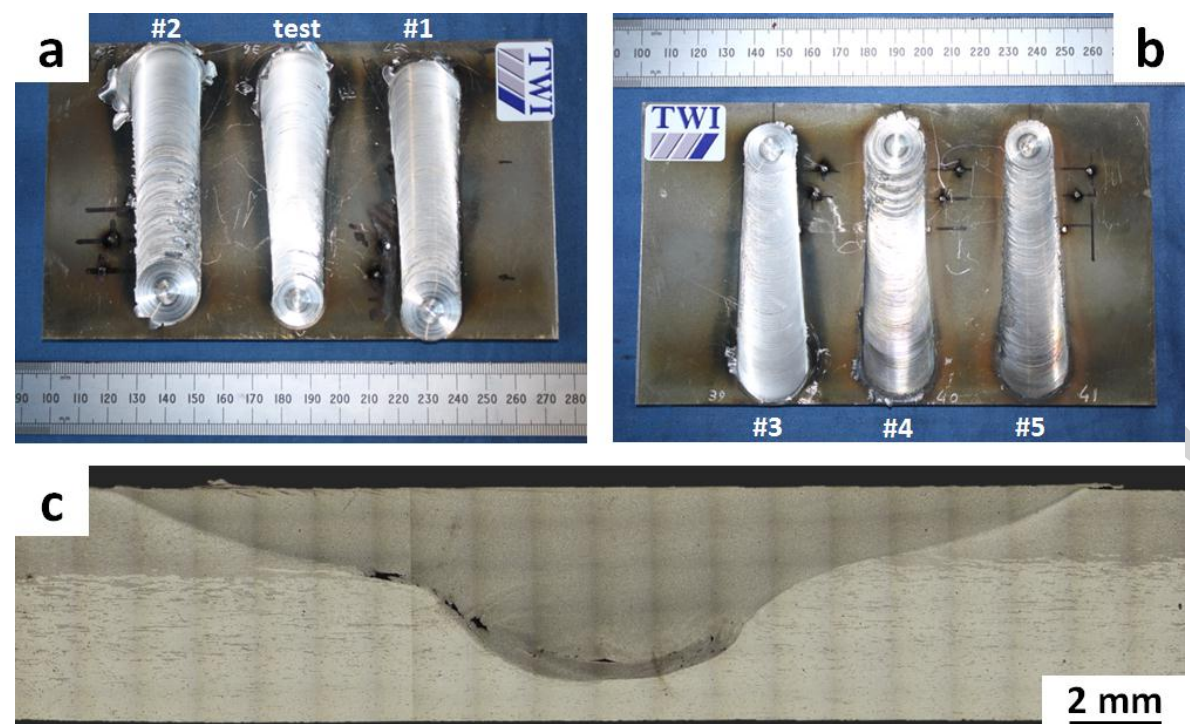

Fig. 1. (a)-(b) Friction stir welds of ODS steel produced in this study, The welding parameters used for each of the welds are collected in Table 2. (c) Optical micrograph of the cross section of \#2. Advancing side on the right of the cross section.

Fig. 1 shows the five bead-on-plate friction stir welds produced, together with an optical

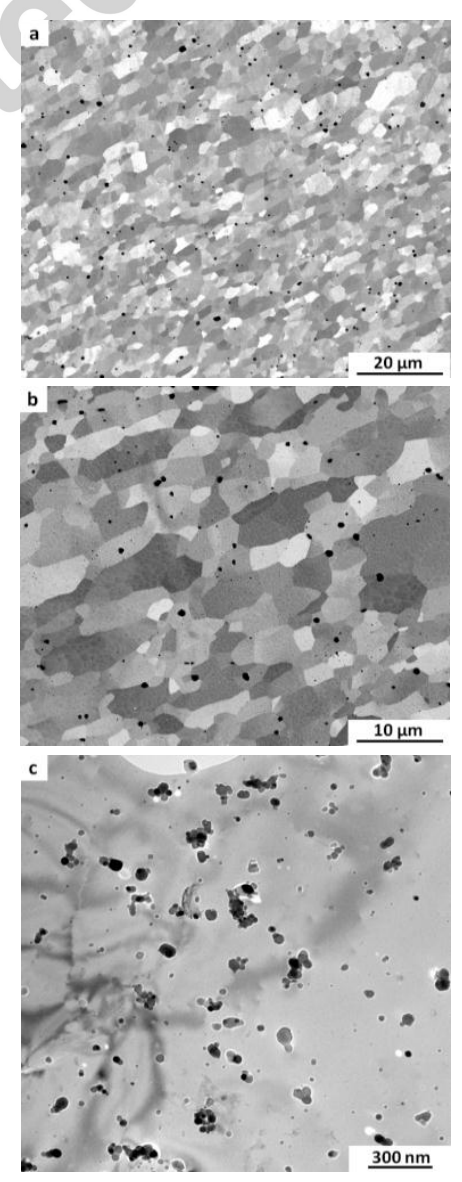




\section{ACCEPTED MANUSCRIPT}

micrograph of a representative weld cross section after chemical etching. The darker central region corresponds to the thermo-mechanically affected zone (TMAZ), where the tool has stirred the material leaving a significantly altered microstructure. The surrounding base material presents two different grain structures: a fine grained section, with a grain diameter in the matrix of $\sim 1-2 \mu \mathrm{m}$, located towards the top of the plate, and beneath that is a section dominated by coarse grains elongated along the axis of extrusion, hundreds of microns thick and several millimetres long. The origin of this dual microstructure is the incomplete abnormal grain growth that only occurred in the near-surface regions of the original plate, during the high-temperature annealing at $1320^{\circ} \mathrm{C}$ prior to the welding process. The plates were oriented with the fine grain structure on the topside for all of the welds.

Fig. 2. (a)-(b) BSE images of the TMAZ of \#1 and \#2, respectively. c) Transmission electron micrograph of the TMAZ of \#3.

The microstructure in the TMAZ can be seen in Fig. 2. Fig. 2(a)-(b) correspond to BSE images taken at the centre of the weld, approx. $1.5 \mathrm{~mm}$ from the top surface of the weld. The TMAZs are comprised of a roughly equiaxed grain structure with a nearly random grain orientation distribution. The mean grain diameter in the ferritic matrix of the welds measured at this location was in the range of $1.9-2.6 \mu \mathrm{m}$, see Table 3, as determined by Electron BackScatter Diffraction (EBSD) [19]. Furthermore, the welding process induces significant agglomeration of the nano-oxide particle dispersion in all the welds, as evidenced by transmission electron microscopy (Fig. 2c).

Table 3.Welding parameters and characteristic parameters of the welded microstructures: mean grain diameter of the ferritic matrix, and relative volume fraction and mean diameter of the oxide nano-particles. 'BM' denotes the base material. Data taken from ref. [19]. The table also contains the values of the interparticle spacing $(\lambda)$ and particle strengthening due to Orowan looping $\left(\sigma_{P}\right)$, estimated using Eq. (2) and (3), see text.

\begin{tabular}{|c|c|c|c|c|c|c|c|}
\hline $\begin{array}{l}\text { Weld } \\
\text { No. \# }\end{array}$ & $\begin{array}{l}\text { Rotations } \\
\text { per Minute } \\
\quad(\text { rpm })\end{array}$ & $\begin{array}{c}\text { Traverse } \\
\text { Speed } \\
(\mathrm{mm} / \mathrm{min})\end{array}$ & $\begin{array}{c}\text { Mean Grain } \\
\text { Diameter } \\
(\mu \mathrm{m})\end{array}$ & $\begin{array}{c}\text { Relative } \\
\text { Volume } \\
\text { Fraction }\end{array}$ & $\begin{array}{l}\text { Mean Particle } \\
\text { Diameter (nm) }\end{array}$ & $\begin{array}{c}\text { Interpart. } \\
\text { Spacing } \\
\lambda(\mathrm{nm})\end{array}$ & $\begin{array}{c}\text { Orowan } \\
\text { Strengthening } \\
\sigma_{p}(\mathrm{MPa})\end{array}$ \\
\hline BM & - & - & - & 1 & $10.8(1)$ & 96 & 241 \\
\hline 1 & 200 & 140 & $2.49(5)$ & 0.64 & $16.0(1)$ & 182 & 141 \\
\hline 2 & 200 & 120 & $2.58(6)$ & 0.53 & $18.8(1)$ & 236 & 113 \\
\hline 3 & 200 & 160 & $2.05(3)$ & 0.77 & $10.8(1)$ & 111 & 209 \\
\hline
\end{tabular}




\begin{tabular}{lllllrrr} 
& \multicolumn{7}{c}{ ACCEPTED MANUSCRIPT } \\
$\mathbf{4}$ & 220 & 140 & $2.56(5)$ & 0.58 & $17.2(1)$ & 206 & 127 \\
$\mathbf{5}$ & 180 & 140 & $1.93(4)$ & 0.83 & $11.4(1)$ & 113 & 209
\end{tabular}

\subsection{Hardness measurements}

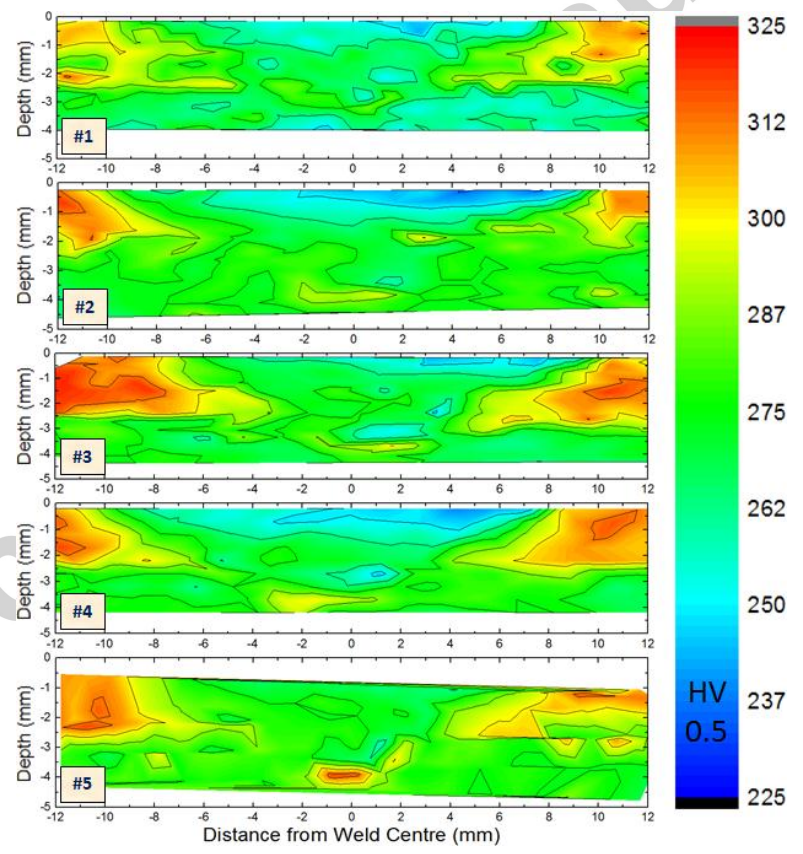

Fig. 3. Hardness maps of the cross sections of the welds. The weld number is indicated in the bottom left corner of each map.

Fig. 3 shows the hardness maps of the weld cross sections. The hardest areas, to the top right and top left of all the maps, are due to the fine grained microstructure of the base material present at these locations. Below these regions there is the coarse grained material which has 


\section{ACCEPTED MANUSCRIPT}

a significantly lower hardness. The TMAZ in all the studied welds presents hardness values that are lower than the surrounding fine grained microstructure, but are either similar or somewhat lower than the hardness values in the coarse grained region of the base material. The lowest hardness is located close to the surface of the welds, particularly on the advancing side. The welds show a heat affected zone (HAZ) of the order of $1 \mathrm{~mm}$ thin, in which there is an intermediate hardness between the TMAZ and fine grained base material.
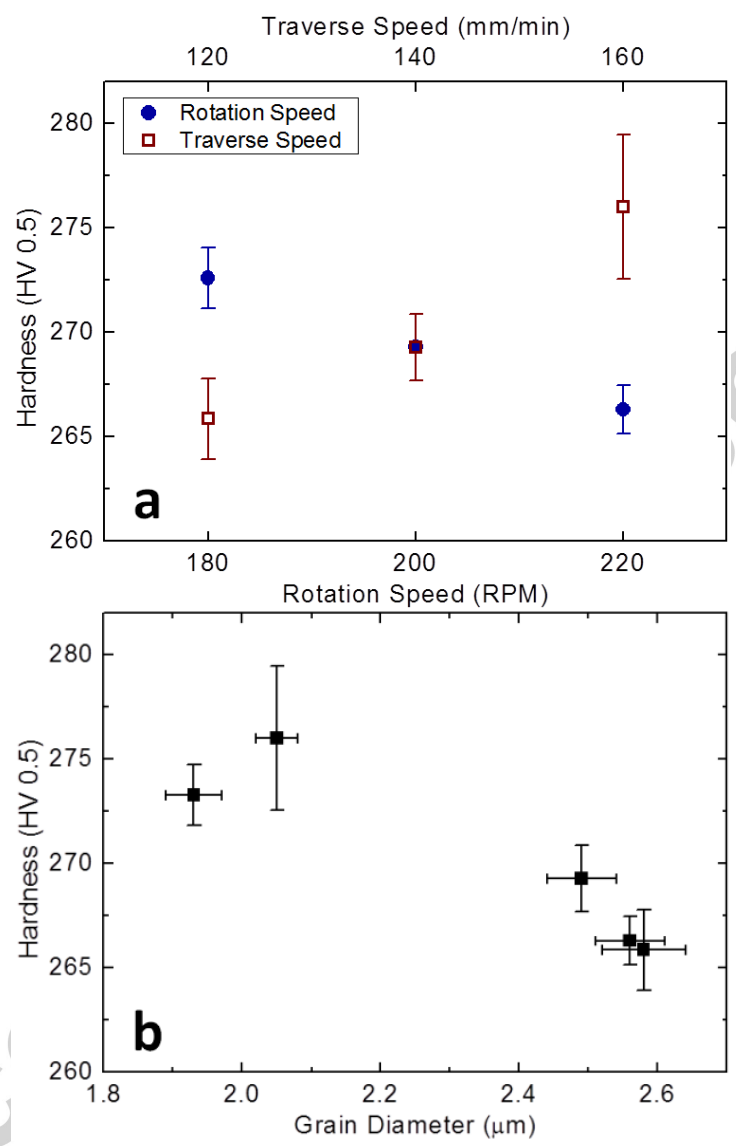

Fig. 4. Mean hardness in the TMAZ of the welds as a function of (a) the rotation and traverse speed of the welding tool, and (b) the mean grain diameter of the ferritic matrix.

Fig. 4 shows the variation of the mean hardness in the TMAZ of the welds with the welding parameters used, Fig. 4(a), namely the tool rotation and traverse speed, and the mean grain size of the welds, Fig. 4(b). The hardness values were calculated by taking the mean value of the data within $\sim 1.5 \mathrm{~mm}$ of the centre of the weld at $\sim 1.5 \mathrm{~mm}$ depth, which corresponds to the same location used for the EBSD maps from which the values of the 


\section{ACCEPTED MANUSCRIPT}

grains size were determined and from where BSE images in Fig. 2(a)-(b) were taken. The mean hardness data reveal a strong correlation between the hardness and the studied welding parameters, i.e. higher hardness values for increasing traverse speed and decreasing with rotation speed. Fig. 4(b) also points to an inverse correlation between the grain size and the mean hardness. The lowest hardness values are present in Weld \#2 (200 rpm and 120 $\mathrm{mm} / \mathrm{min}$ ) and Weld \#4 (220 rpm and $140 \mathrm{~mm} / \mathrm{min})$. These two welds have the highest mean grain size, and also the widest TMAZs of the studied welds.

\subsection{Tensile testing}
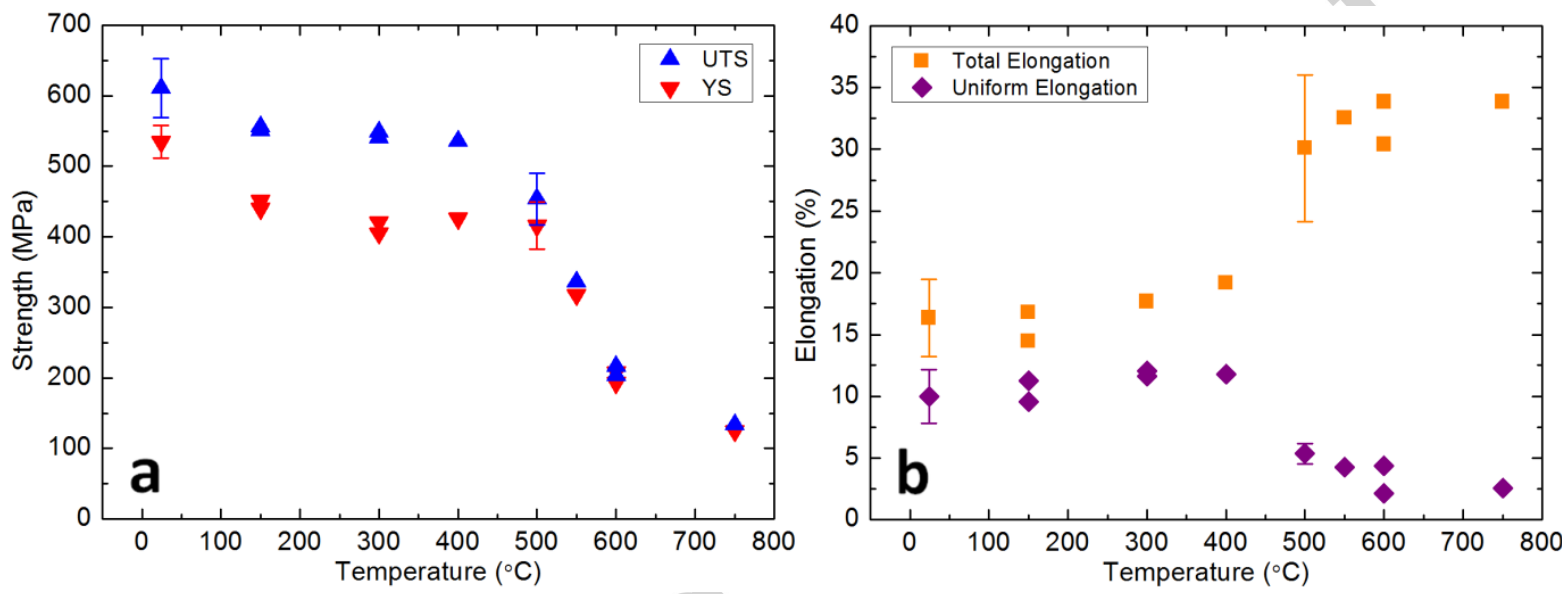

Fig. 5. Mechanical properties of the coarse grained base material as a function of temperature. (a) Tensile strength, where YS and UTS represent yield stress and ultimate tensile stress, respectively. (b) Total and uniform elongation.

The temperature dependence of the mechanical properties of the base material is shown in

Fig. 5. At room temperature the coarse grained material has a $0.2 \%$ offset yield stress (YS) of 535(24) $\mathrm{MPa}$ and an ultimate tensile stress (UTS) of 610(42) MPa. In the temperature regime of 150 to $400^{\circ} \mathrm{C}$, both the YS and UTS remain relatively constant with values of $\sim 430$ and $545 \mathrm{MPa}$, respectively. However, at $500^{\circ} \mathrm{C}$ the strength of the material starts to decrease progressively with temperature. This reduction in strength is accompanied by a drastic change in ductility, Fig. 5(b). Above $400^{\circ} \mathrm{C}$ the uniform elongation decreases while the total elongation significantly increases with temperature. At $750^{\circ} \mathrm{C}$ the total elongation is more 


\section{ACCEPTED MANUSCRIPT}

than twice its value at room temperature, whereas the uniform elongation at that temperature is below $3 \%$.
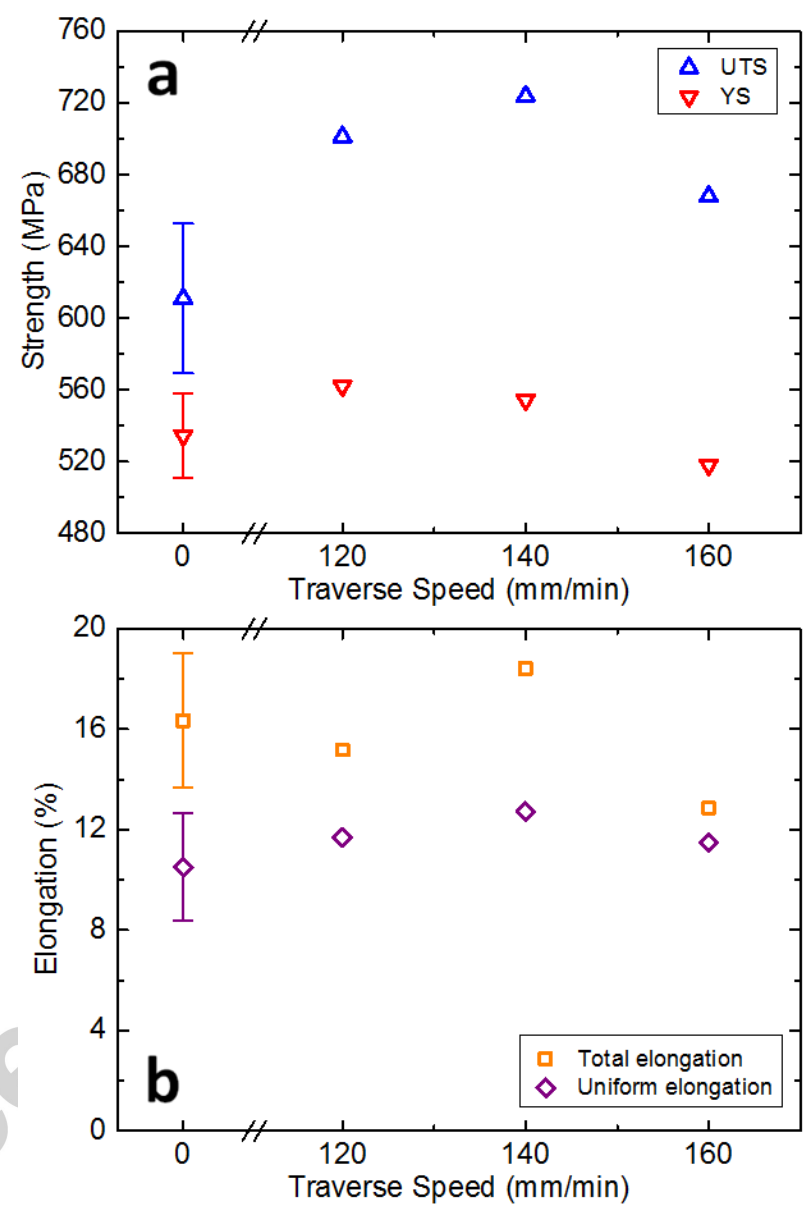

Fig. 6. Mechanical properties of the welds and base material tested at room temperature as a function of tool traverse speed, using a value of zero for the traverse speed in the case of the base material. (a) Tensile strength and (b) elongation.

The mechanical properties of the welds at room temperature, together with the corresponding values of the base material as reference, are shown in Fig. 6. At room temperature the YS of the base material is similar to that of the different welds. Weld \#1 had the highest YS with a value of $554 \mathrm{MPa}$, but this is only slightly greater than the mean value 


\section{ACCEPTED MANUSCRIPT}

for the base material of 535(24) MPa. The ultimate tensile strength of the welds at room temperature is noticeably increased by $\sim 8-16 \%$ as compared to the base material. The elongation after welding was similar to the base material and no trend in elongation with the traverse speed was observed at room temperature; see Fig. 6(b).

The tensile behaviour of the welds in the $500^{\circ} \mathrm{C}$ regime can be seen, below, in Fig. 7 . The increase in temperature up to $500^{\circ} \mathrm{C}$ causes a significant decrease in both the YS and UTS of all the welds. The YS of all the welds tested lie within $5 \%$ of the corresponding value of the base material at that temperature. The UTS values for the welds were all between $~ 5$ $15 \%$ greater than the corresponding value of the base material.
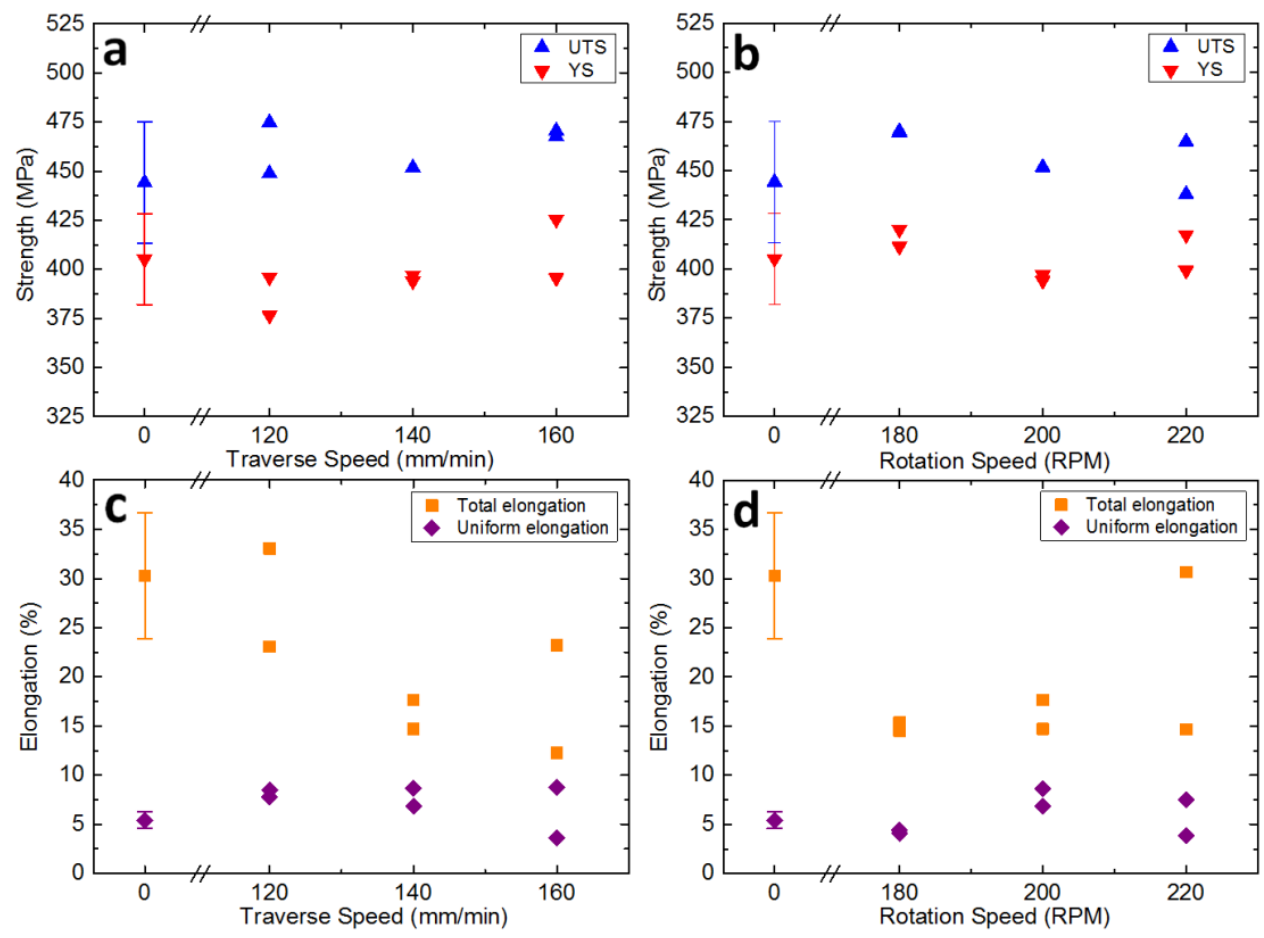

Fig. 7. Mechanical properties of the welds and base material tested at $500^{\circ} \mathrm{C}$, as a function of welding parameters. (a) Tensile strength vs. traverse speed. (b) Tensile strength vs. rotation speed. (c) Elongation vs. traverse speed and (d) elongation vs. rotation speed.

\subsection{Fractography}

Representative fracture surfaces of the base material at variable temperatures, and also of selected welds at room temperature and at $500^{\circ} \mathrm{C}$, are displayed in Fig. 8. There seems to be 


\section{ACCEPTED MANUSCRIPT}

three main fracture modes for the base material, depending on the test temperature: (i) at room temperature, the material fails by an almost purely brittle fracture mode, although some areas of the fracture surface present dimples (Fig. 8 BM-RT). Delamination of the coarse grain structure was also observed at room temperature; there was splitting of the specimen parallel to the rolling direction and long specimen axis. (ii) At $150-400^{\circ} \mathrm{C}$, we observed a mixed ductile-brittle fracture surface with small dimples. At these intermediate temperatures there was a tendency for shearing fracture, where the cleavage surface runs at $45^{\circ}$ to the direction of the applied load (Fig. $8 \mathrm{BM}-150^{\circ} \mathrm{C}$ and $\mathrm{BM}-300^{\circ} \mathrm{C}$ ). (iii) Above $500^{\circ} \mathrm{C}$, a ductile failure mechanism dominates. The fracture surface no longer runs at $45^{\circ}$, and instead pronounced necking and microvoid coalescence occurs prior to fracture (Fig. 8 $\left.\mathrm{BM}-600^{\circ} \mathrm{C}\right)$. In the case of the test specimens from the welds, necking and a dimpled fracture surface was observed both at room temperature and $500^{\circ} \mathrm{C}$, resembling those fracture surfaces of the base material at intermediate temperatures.
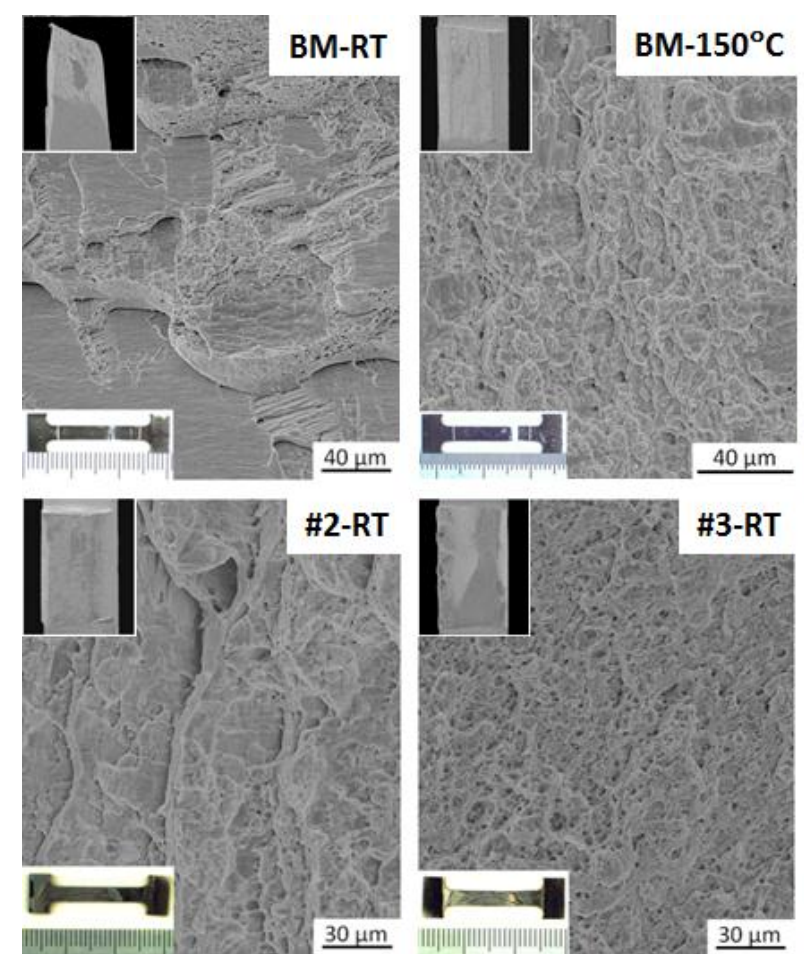
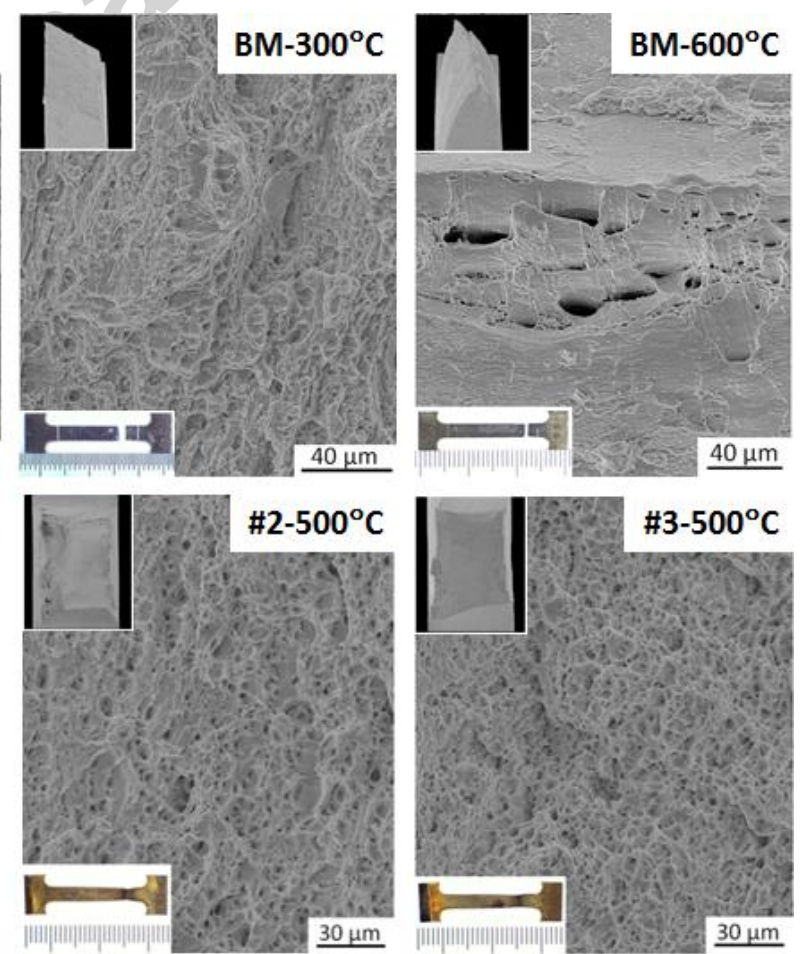

Fig. 8. Scanning electron micrographs of the fracture surface of the base material (BM) and two representative welds (\#2 and \#3) at variable temperatures. The base material specimens shown have been chosen to be representative of the three main fracture modes. 


\section{ACCEPTED MANUSCRIPT}

\section{Discussion}

The width of the weld cross section increased with both increasing rotation speed and decreasing traverse speed of the welding tool. This effect can be attributed to the higher peak temperatures reached during welding with faster rotation speed, as a consequence of the greater heating and adiabatic shear. Lower traverse speeds also mean that the heat is retained locally for a longer period of time. More energy is thus available, and for longer, to propagate by conduction into the surrounding metal and hence there is also a larger HAZ.

These parameters also lead to lower hardness values for their respective welds. We measured a peak temperature of $943^{\circ} \mathrm{C}$ for a rotation speed of $200 \mathrm{rpm}$ and the lowest traverse speed of $120 \mathrm{~mm} / \mathrm{min}$ in the steady-state regime during the welding of a very similar butt weld [20].

Based on the data in Table 3, as the rotation speed was increased or the traverse speed decreased, the volume density of nano-oxide particles decreased and the grain size in the surrounding ferritic matrix consequently increased [19]. It should be noted that the particle volume fractions in Table 3, as probed by small angle neutron scattering (SANS), only apply to particles less than $80 \mathrm{~nm}$ in diameter. Particles and agglomerates larger than this value fell beyond the size range probed by our previous SANS experiment. With fewer particles and larger grains, there are fewer obstacles for dislocations to overcome and the hardness, which is a measure of the material's resistance to plastic flow, therefore reduces.

The correlation between peak temperatures during welding and hardness also explains the heterogeneity in hardness across the TMAZ, which generally presents lower hardness values towards the top of the welds, particularly on the advancing side of the weld. The hottest locations during welding will be just beneath the rotating shoulder of the welding tool, particularly on the advancing side where the relative velocity of the tool is greater. We could expect in this location for there to be fewer oxide particles and a larger grain size, as a result 


\section{ACCEPTED MANUSCRIPT}

of the greater temperatures and strains at these locations. Dawson et al. [21] recently found an increased mean particle size close to the surface of friction stir weld in PM2000 steel.

The room-temperature yield stress of a material can in general be expressed as a sum of its main strengthening components, assuming that they operate independently $[7,9,22]$ :

$$
\sigma_{Y}=\sigma_{O}+\sigma_{S S}+\sigma_{D}+\sigma_{P}+\sigma_{G B}
$$

where $\sigma_{0}$ represents the Peierls-Nabarro stress or the intrinsic stress due to resistance of dislocation motion in the matrix, $\sigma_{\mathrm{SS}}$ the solid solution strengthening caused mainly by the $\mathrm{Cr}$ atoms present in the ferritic matrix and amounts to $8.5 \mathrm{MPa} / \mathrm{wt} . \%$ [11], $\sigma_{\mathrm{D}}$ the strengthening due to dislocations, $\sigma_{\mathrm{P}}$ the particle strengthening and $\sigma_{\mathrm{GB}}$ the grain boundary strengthening. The reported value of $\sigma_{0}$ for pure annealed Fe is $50 \mathrm{MPa}$ [11]. We can assume that $\sigma_{0}$ and $\sigma_{\mathrm{SS}}$ are constant for both the base material and the welds. The base material underwent recrystallization during processing and the TMAZ during welding, consequently leaving both microstructures with a relatively low dislocation density. The change in strengthening due to dislocations has therefore not been further considered. The strengthening contribution due to Orowan looping of dislocations around the non-shearable oxide particles, $\sigma_{\mathrm{P}}$, is given by:

$$
\sigma_{P}=\frac{0.4}{\pi} \frac{M G b}{(1-v)^{0.5}} \frac{\ln \left(\frac{2 r}{b}\right)}{\lambda}
$$

where $\mathrm{M}$ is the Taylor factor (2.7), $G$ is the shear modulus (60 GPa), $b$ is the Burger's vector $(0.25 \mathrm{~nm})$ and $v$ is the Poisson's ratio (0.3). The values in parenthesis are taken from [11]. $r$ is the mean radius of the nanoparticles, and $\lambda$ is the mean interparticle spacing given by:

$$
\lambda=\left[\left(\frac{3 \pi}{4 f}\right)^{0.5}-1.64\right] r
$$

The values of $\sigma_{P}$ and $\lambda$ for the base material and the different welds are collected in Table 3 . The grain boundary strengthening can be expressed as a function of the grain size $d$ via the Hall-Petch type expression: 


$$
\sigma_{G B}=k_{H P} \cdot d^{-0.5}
$$

where $k_{H P}$ is the Hall-Petch constant which other authors on ODS steels have used or determined to be $~ 0.2-0.6 \mathrm{MPa} \mathrm{m}^{0.5}[9,23,24]$. Welding induces a significant grain refinement in the matrix, as compared to the coarse grain structure of the tested base material. The associated increase in grain boundary strengthening seems to compensate for the particle agglomeration and dissolution observed in the different welds, so that the yield strength after welding remains close to the value for the base material in all studied welds, see data in Fig. 6(a) and Fig. 7(a)-(b). Assuming a Zener pinning effect of the particles on the ferrite grain size, the maximum achievable ratio between the grain boundary and particle strengthening contributions can be expressed as $[23,25]$ :

$$
\frac{\sigma_{G B}}{\sigma_{P}}=\frac{k_{H P}}{M G b}\left(\frac{\pi d_{P}}{3}\right)^{1 / 2}
$$

where $d_{P}$ corresponds to the mean particle diameter. Based on the previously mentioned values for the parameters included in Eq. (5), the grain boundary strengthening contribution would be comparable to or even greater than the particle strengthening at particle sizes $d_{P}>$ 4-40 nm, depending on the value used for the $k_{H P}$ constant.

Using Eq. 2 and 3, and with the values for the volume fraction and the mean nanoparticle size for the base material given in Table 3, we estimated the strengthening contribution from the fine $(<80 \mathrm{~nm})$ particles to be $241 \mathrm{MPa}$. Following FSW, we calculated that the reduction in particle strengthening to be $\sim 13-53 \%$ (Table 3) depending on the weld microstructure. These calculations suggest that there should be a relatively large amount of variation in the strengthening for the different welds, and a correlation with the oxide particle size and density, especially since the welds with lower particle density also have larger grain sizes. However, this expected variation was not observed in the experimental values of the yield stress as a function of welding parameters. A significant number of oxide particles tend 


\section{ACCEPTED MANUSCRIPT}

to form agglomerates larger than $>80 \mathrm{~nm}$, rather than dissolving into the matrix. Although larger particles are in general less effective at strengthening, for a given volume fraction, it seems as though these agglomerates are still contributing significantly to the strength of the welds. Due to the relatively high number density of agglomerates, they are likely to provide a somewhat greater strengthening contribution than the other large particle populations present in the microstructure from the ODS steel production, namely Al-O-based particles and $\operatorname{Ti}(\mathrm{CN})$ in MA956 steel. The number of agglomerates over $80 \mathrm{~nm}$ was likely to be greatest for the welds with increased rotation speed or decreased traverse speed of the welding tool, due to greater levels of mixing, and these were the welds with greatest measured reduction in nanoparticle volume fraction.

A sharp decrease in both the YS and the UTS of the base material and the welds has been observed in the vicinity of $500^{\circ} \mathrm{C}$. Below that temperature, the variation of the Orowan stress with temperature arises mainly from changes in the matrix shear modulus $G$ [22]. However at higher temperatures, the dispersed particles can be overcome by dislocation climb and the strengthening contribution from Orowan looping, which is dominant at lower temperatures, becomes diminished. The particles do still offer a non-negligible strengthening contribution at high temperatures, via an attractive particle-dislocation interaction after the dislocation has climbed over the particle [26-29]. The particle-dislocation interaction is however not able to produce stress exponents as high as Orowan looping, and we observe a sharp drop in strength as thermal effects overcome the activation energy for dislocation detachment. In addition to the temperature dependence of the Orowan particle strengthening mechanism, the grain boundary strengthening contribution falls quickly at high homologous temperatures, e.g. $\mathrm{T} / \mathrm{T}_{\mathrm{m}}>0.4$, even though the grain size doesn't change significantly at temperatures close to $500^{\circ} \mathrm{C}$. The transition temperature decreases with the grain size of the matrix $[23,30]$. This temperature effect on the grain boundary strengthening has been 


\section{ACCEPTED MANUSCRIPT}

successfully modelled based on a steady-state deformation mechanism involving the thermally-activated absorption of dislocations at grain boundaries [23]. Due to the lack of grain boundary strengthening at elevated temperatures, it is of even greater importance that the particle dispersion of the weld is as close as possible to that of the base material, so that the welds are still able to offer as much strength as possible at these elevated temperatures, whether or not it is decided to keep the refined microstructure or induce abnormal grain growth post weld [12]. The relatively close values for the YS and UTS observed for the welds and the base material at $500^{\circ} \mathrm{C}$ seem promising in terms of ODS steels' prospective implementation in future nuclear reactors.

The uniform and total elongation in the base material present relatively close values to one another, and both remain close to constant with temperature up to $400^{\circ} \mathrm{C}$ (Fig. 5(b)). At higher temperatures the total elongation increases progressively, whereas the uniform elongation reduces simultaneously. The welds retain a comparable strength to the BM at both room temperature and $500^{\circ} \mathrm{C}$, (Fig. 6(a) and 7(a)-(b)). This is the case for both YS and UTS, except at room temperature where the UTS of the welds was superior to the BM. The inspection of the fracture surfaces in Fig. 8(top row) revealed a change in fracture mode from brittle at room temperature, to a mixed brittle-ductile at $150-400^{\circ} \mathrm{C}$ and further to pure ductile fracture above $400^{\circ} \mathrm{C}$. For the MA956 base material, the ductile-to-brittle transition temperature is reported to take a value of $40-70^{\circ} \mathrm{C}$ [31]. At room temperature, the work hardening of the base material is low, and fracture occurs relatively quickly after the UTS is reached and generates a predominantly brittle-like fracture surface. On the contrary, at temperatures higher than $400^{\circ} \mathrm{C}$, the fracture surface is characterised by a number of relatively large equiaxed dimples. This fact may imply that void nucleation at high temperatures takes place at local strain concentrations close to second phase micron-sized particles for relatively low strain levels, probably induced by dislocation pile-ups and 


\section{ACCEPTED MANUSCRIPT}

decohesion of the particle/matrix interface, and therefore leads to relatively low values of uniform elongation. However, significant plastic deformation is still needed to induce fracture, as revealed by the increased necking and total elongation. In contrast, the welded microstructures are characterised by a fine grained structure and a significant number of particle agglomerates that can be larger than $100 \mathrm{~nm}$ diameter, see Fig. 2. This means that there are a higher number of void nucleation sites in the welded region as compared to the coarse grained base material, i.e. grain boundaries and particle agglomerates [32]. Consequently, the ductile fracture surface of the welds, see Fig. 8(bottom row), is characterised by a large number of roughly equiaxed dimples resulting from the random distribution of coalesced voids.

\section{Conclusions}

We have investigated the temperature-dependent mechanical behaviour of MA956 ODS steel before and after friction stir welding. The coarse grained base material retains a relatively large proportion of its room-temperature strength up to $500^{\circ} \mathrm{C}$. At higher temperatures both the yield stress and the ultimate tensile stress decrease with temperature, whereas the total elongation increases. The strength and ductility of the welds are similar to those of the base material, both at room temperature and at $500^{\circ} \mathrm{C}$. The decrease in particle strengthening due to agglomeration in the welds is compensated by the grain boundary strengthening due to the finer grain structure of the welds as compared to the base material. Furthermore, the additional presence of submicron-sized particle agglomerates and a higher grain boundary density in the welded regions seems to increase the number of void nucleation sites. Consequently the fracture surfaces of the welds comprise of a much larger number of smaller equiaxed dimples. No trend in mechanical properties of the welds was observed from the tensile data, but an increase in hardness was observed with increasing traverse speed or 


\section{ACCEPTED MANUSCRIPT}

decreasing rotation speed, due to the finer grain size and larger number of strengthening nano-particles present in these welds.

\section{Acknowledgements}

We gratefully acknowledge the financial support of the Engineering and Physical Sciences Research Council UK (EPSRC) through the Centre for Doctoral Training in Advanced Metallic Systems (EP/L016273/1). We would like to thank The Welding Institute (TWI) for providing the welding tools and assistance during friction stir welding. We also acknowledge CIEMAT for providing the MA956 base material and performing the tensile tests and SEM imaging of the fracture surfaces. This work contributes to the Joint Programme on Nuclear Materials (JPNM) of the European Energy Research Alliance (EERA).

\section{References}

[1] P. Yvon, F. Carré, Structural materials challenges for advanced reactor systems, J. Nucl. Mater. 385 (2009) 217-222.

[2] J.-L. Boutard, V. Badjeck, L. Barguet, C. Barouh, A. Bhattacharya, Y. Colignon et al., Oxide dispersion strengthened ferritic steels: a basic research joint program in France, J. Nucl. Mater. 455 (2014) 605-611.

[3] M. Gorley, Critical Assessment 12: Prospects for reduced activation steel for fusion plant, Mater. Sci. Technol. 31 (2015) 975-980.

[4] A. Hirata, T. Fujita, Y. R.Wen, J. H. Schneibel, C. T. Liu, M.W. Chen, Atomic structure of nanoclusters in oxide-dispersion-strengthened steels. Nature Mater. 10 (2011) 922-926.

[5] Y. Wu, J. Ciston, S. Kräemer, N. Bailey, G. R. Odette, P. Hosemann, The crystal structure, orientation relationships and interfaces of the nanoscale oxides in nanostructured ferritic alloys. Acta Mater. 111 (2016) 108-115.

[6] G. Odette, Recent Developments in Irradiation-Resistant Steels, Annu. Rev. Mater. Res. 38 (2008) 471-503. 


\section{ACCEPTED MANUSCRIPT}

[7] S.Y. Zhong, V. Klosek, Y. de Carlan, M.H. Mathon, Modeling of structural hardening in oxide dispersion-strengthened (ODS) ferritic alloys. J. Mater. Sci. 51 (2016) 2540-2549.

[8] R.S. Mishra, Z.Y. Ma, Friction stir welding and processing. Mater. Sci. Eng. R 50 (2005) $1-78$.

[9] B.W. Baker, T.R. McNelley, L.N. Brewer, Grain size and particle dispersion effects on the tensile behavior of friction stir welded MA956 oxide dispersion strengthened steel from low to elevated temperatures. Mater. Sci. Eng. A. 589 (2014) 217-227.

[10] K. Yabuuchi, N. Tsuda, A. Kimura, Y. Morisada, H. Fujii, H. Serizawa, et al., 2014. Effects of tool rotation speed on the mechanical properties and microstructure of friction stir welded ODS steel. Mater. Sci. Eng. A. 595 (2014) 291-296.

[11] J. Wang, W. Yuan, R.S. Mishra, I. Charit, Microstructure and mechanical properties of friction stir welded oxide dispersion strengthened alloy, J. Nucl. Mater. 432 (2013) 274-280.

[12] B. Mazumder, X. Yu, P.D. Edmondson, C.M. Parish, M.K. Miller, H.M. Meyer III, et al., Effect of friction stir welding and post-weld heat treatment on a nanostructured ferritic alloy. J. Nucl. Mater. 469 (2016) 200-208.

[13] R. Nandan, T. DebRoy, H.K.D.H. Bhadeshia, Recent advances in friction-stir welding Process, weldment structure and properties. Progress in Materials Science 53 (2008) 9801023.

[14] R.S. Mishra, P. Sarathi De, N. Kumar, Friction Stir Welding and Processing, Springer, 2014.

[15] H. Zhu, Development of Oxide Dispersion Strengthened Steels for High Temperature Nuclear Structural Applications, in Engineering Asset Management and Infrastructure Sustainability, Springer, 2012, pp. 1147-1160.

[16] Engineering Data Sheet for Incoloy MA956, Special Metals Corporation, 2004.

[17] J.D. Whittenberger. Metall. Trans. A. 12A (1981) 845. 


\section{ACCEPTED MANUSCRIPT}

[18] R.C. Klug, G. Krauss, D.K. Matlock. Metall. Mater. Trans. A. 27 (1996) 1945.

[19] H. Dawson, M. Serrano, S. Cater, N. Iqbal, L. Almásy, Q. Tian, E. Jimenez-Melero. Impact of Friction Stir Welding on the microstructure of ODS steel. J. Nucl. Mater. 486 (2017) 129-137.

[20] H. Dawson, M. Serrano, S. Cater, N. Iqbal, P. Wady, P. Thirling, E Jimenez-Melero, Residual Stress Distribution in Friction Stir Welded ODS Steel Measured by Neutron Diffraction. J. Mater. Process. Technol. (In Press).

[21] K. Dawson, S. Cater, G.J. Tatlock, C. Stanhope, Friction stir welding of PM2000 ODS alloy. Mater. Sci. Technol. 30 (2014) 1685-1690.

[22] J. Martin, Micromechanisms in particle-hardened alloys, New York: Cambridge University Press, 1980.

[23] J.H. Schneibel, M. Heilmaier, W. Blum, G. Hasemann, T. Shanmugasundaram, Temperature dependence of the strength of fine- and ultrafine-grained materials, Acta Mater. 59 (2011) 1300-1308.

[24] J.H. Kim, T.S. Byun, D.T. Hoelzer, C.H. Park, J.T. Yeom, J.K. Hong, Temperature dependence of strengthening mechanisms in the nanostructured ferritic alloy 14YWT: Part II-Mechanistic models and predictions. Mater. Sci. Eng. A. 559 (2013) 111-118.

[25] P.M. Hazzledine, Direct versus indirect dispersion hardening, Scripta Metall. Mater. 26 (1992) 57-58.

[26] E. Arzt, J. Rössler, The kinetics of dislocation climb over hard particles - II. Effects of an attractive particle-dislocation interaction. Acta Metall. 36 (1988) 1053.

[27] R.S. Herrick, J.R. Weertman, R. Petkovic-Luton, M.J. Luton, Dislocation/particle interactions in an oxide dispersion strengthened alloy. Scripta Metall. 22 (1988) 1879-1884 


\section{ACCEPTED MANUSCRIPT}

[28] M. Bartsch, A. Wasilkowska, A. Czyrska-Filemonowicz, U. Messerschmidt, Dislocation dynamics in the oxide dispersion strengthened alloy INCOLOY MA956, Mater. Sci. Eng. A. 272 (1999) 152-162.

[29] R. Mishra, Dislocation-particle interaction at elevated temperatures, JOM. 62 (2009) $52-55$.

[30] J.H. Schneibel, M. Heilmaier, Hall-Petch Breakdown at Elevated Temperatures, Mater. Trans. 55 (2014) 44-51.

[31] R. Salomon, Incoloy alloy MA956. Incoloy alloy MA956. Strain rate and temperature effects on the microstructure and ductility, J. Physique IV. 3 (1993) C7-697.

[32] C. Yen, T.E. Howson, F. Cosandey, J.K. Tien, Creep fracture processes of oxide dispersion strengthened mechanically alloyed inconel alloy ma754. Metall. Trans. A. 13 (1982) 2286-2288.

GA
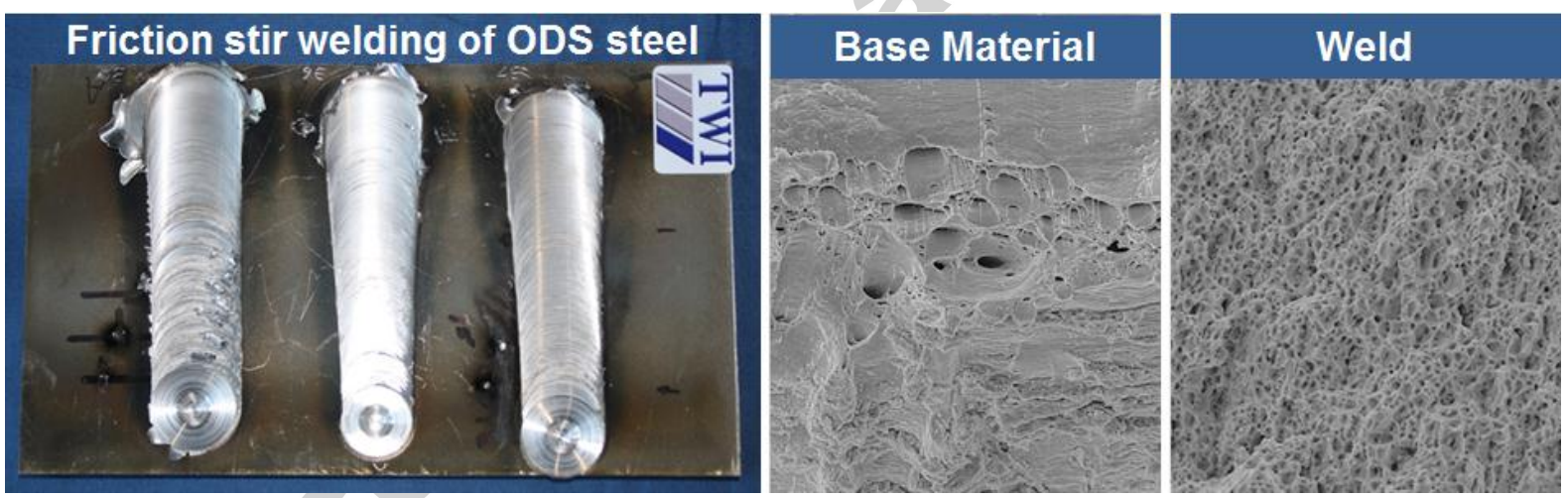